\title{
The Effect of Rusa unicolor Antler Deer Extracts from East Kalimantan in Bone Turnover Cell Models
}

\section{Doğu Kalimantan'dan Rusa unicolor Geyiği Boynuzu Ekstraktlarının Kemik Dönüşümü Hücre Modelleri Üzerine Etkisi}

\author{
(D) Retno WIDYOWATI ${ }^{*}$, (D) Suciati SUCIATI ${ }^{1}$, (D) Dewi Melani HARYADI2, (D) Hsin-I CHANG ${ }^{3}$, (D) IPG Ngurah SURYAWAN4 ${ }^{4}$, (D) Agung Widi UTAMA 4 \\ 1Airlangga University Faculty of Pharmacy, Department of Pharmacognosy and Phytochemistry, Surabaya, Indonesia \\ 2Airlangga University Faculty of Pharmacy, Department of Pharmaceutics, Surabaya, Indonesia \\ 3National Chiayi University Clinic of Biochemical Science and Technology, Taiwan, China \\ 4UPTD Pembibitan dan Inseminasi Buatan, Dinas Peternakan dan Kesehatan Hewan Provinsi Kalimantan Timur, Indonesia
}

\begin{abstract}
Objectives: Osteoporosis is a condition characterized by skeletal degradation of osseous tissue resulting in an escalated chance of broken bones. Traditionally, Rusa unicolor horn from East Kalimantan is used to treat many diseases, including conditions associated with bone turnover. The aim of the present research was to analyze the effects of $70 \%$ ethanol and aqueous extracts of $R$. unicolor antler's horn from East Kalimantan on nitric oxide inhibition, osteoblast differentiation, and mineralization related to bone turnover.

Materials and Methods: Nitric oxide inhibition of the extracts in lipopolysaccharide-stimulated RAW 264.7 macrophages was evaluated by Griess reagent, while the effects of extracts on osteoblast differentiations were measured by alkaline phosphatase in $p$-nitrophenyl phosphate. Their effects on mineralization was determined using alizarin red staining.

Results: The $70 \%$ ethanol and aqueous extracts inhibited cell inflammation (40\% and $80 \%$, respectively) and stimulated osteoblast differentiation ( $65 \%$ and $52 \%$, respectively). In the mineralization test, the aqueous extract showed an effect two times higher than that of $70 \%$ ethanol extract.

Conclusion: The extracts can effectively degrade inflammatory marker expression and preserve osteoblast functions.
\end{abstract}

Key words: Rusa unicolor, antler, alkaline phosphatase, mineralization, nitric oxide inhibition

öz

Amaç: Osteoporoz artmış kemik kırılmalarıyla sonuçlanan kemik dokusundaki iskelet degredasyonu ile karakterize bir durumdur. Geleneksel olarak, Doğu Kalimantan'dan Rusa unicolor boynuzu kemik dönüşümü dahil, birçok hastalığın tedavisinde kullanılır. Bu çalışmanın amacı Doğu Kalimantan R. unicolor geyiği boynuzunun \%70'lik etanol ve sulu ekstrelerinin nitrik oksit inhibisyonu, osteoblast farklılaşması ve kemik dönüşümüyle ilişkili minerilizasyon üzerine etkilerinin araștırılmasıdır.

Gereç ve Yöntemler: Ekstratların lipopolisakkarit ile stimüle edilen RAW 264,7 makrofajlarında nitrik oksit inhibisyonu Griess belirteciyle değerlendirilirken, ekstrelerin osteoblast farklılașması üzerine etkileri $p$-nitrofenil fosfatta alkalin fosfataz ölçülerek belirlenmiștir. Mineralizasyon üzerine etkileri ise, alizarin kırmızısı kullanılarak belirlenmiştir.

Bulgular: \%70'lik etanol ve sulu ekstrelerinin hücre enflamasyonunu inhibe ettiği (sırasıyla \%40 ve \%80) ve osteoblast farklılaşmasını stimüle ettiği (sırasıyla \%65 ve \%52) belirlenmiştir. Minerilazasyon testinde, sulu ekstre etanol ekstresine göre iki kat daha yüksek etki göstermiştir.

Sonuç: Ekstrelerin etkin bir şekilde enflamasyon belirteci ekspresyonun degrede etmiş ve osteoblast işlevlerini korumaktadır.

Anahtar kelimeler: Rusa unicolor, geyik, alkalin fosfataz, minerilizasyon, nitrik oksit inhibisyonu

*Correspondence: E-mail: rr-retno-w@ff.unair.ac.id, Phone: +6281615886978 ORCID-ID: orcid.org/0000-0003-0572-7551

Received: 18.01.2019, Accepted: 30.05.2019

๑Turk J Pharm Sci, Published by Galenos Publishing House. 


\section{INTRODUCTION}

Osteoporosis is a bone condition characterized by skeletal degradation of osseous tissue leading to an increased chance of broken bones.' It is a condition of old age and supposed to increase with rising age and lifespan. At present, more than 200 million people worldwide are estimated to suffer from osteoporosis. ${ }^{2}$ The latest statistical data from the International Osteoporosis Foundation showed that one in three women above 50 years old and one in five men shall suffer osteoporosis for the rest of their lives. ${ }^{3}$ Indonesia also has the same problem, whereas the number of osteoporosis sufferers is higher than the latest data (>19.7\%). In Indonesia, the number of old people is supposed to increase by $14 \%$ in $1990-2025$, while menopausal women in 2000 contributed to an increase of 15.5 million to 24 million in 2015. ${ }^{4}$

For thousands of years, natural plants and animal resources have played a vital role in the development of pharmaceutical drugs and food supplements for the treatment and prevention of diseases. ${ }^{5}$ One of such resources with great medicinal value is the antler of the deer belonging to the family Cervidae. It is an efficient traditional medicine for strengthening bones and tendons. Researchers assume that the lack of glycosaminoglycans caused disproportion between cartilage erosion and regeneration in osteoarthritis sufferers. These substances have an essential role in cartilage's structural integrity. Glycosaminoglycan is isolated from four parts of the antler of deer (Cervus elaphus), namely the tip, upper part, middle, and base, through cellulose acetate electrophoresis, enzymatic digestion, and chromatography. Chondroitin sulfate, which contains $88 \%$ uronic acid, is the principal glycosaminoglycan. Apart from chondroitin sulfate, deer antler also contains hyaluronic acid, dermatan sulfate, and keratan sulfate in small quantities. ${ }^{6}$ Several researches also report that deer antler can reduce or even eradicate symptoms related to osteoarthritis.

For decades, Chinese people have traditionally used deer antler extract to strengthen bones, enhance virility, feed blood, supplement vitality, and enhance male and female sexual organs. ${ }^{7}$ A good number of products analogous to deer antler show great potency on illnesses related to aging, infection, and immune dysfunction. However, the active constituents responsible for this mechanism are unclear. ${ }^{8-13}$ According to some preclinical studies, deer antler products are able to reduce animals osteoporosis. ${ }^{14-16}$ Lee et al..$^{17}$ showed that facilitation of osteoblast proliferation and mineralization are some of the principal mechanisms of the effects of deer antler products. Furthermore, Choi et al. ${ }^{18}$ reported inhibition of osteoclast differentiation by deer antlers. Protein, calcium, lipids, ash, collagen, proteoglycan, testosterone, cholesterol, estradiol, glutamic acid, insulin-like growth factor 1, iron, aspartic acid, and glycine are some of the constituents contained in antler. 19,20

In the present study, we evaluated $70 \%$ ethanol and aqueous extract of Rusa unicolor antler from East Kalimantan Indonesia toward the effect of osteoblast differentiation, mineralization, and expression of inflammatory markers by measuring alkaline phosphatase (ALP), alizarin red staining (ARS), and nitric oxide (NO) inhibition values, respectively.

\section{MATERIALS AND METHODS}

\section{Cell culture and reagents}

Chemicals such as an acid phosphatase leukocyte kit and ALP colorimetric assay kit were obtained from Sigma-Aldrich Co. (St Louis, MO, USA). Cell culture substances and solvents were bought from Thermo Fisher Scientific (Waltham, MA, USA) and were analytical grade (J.T. Baker, USA). Macrophages (RAW 264.7) and osteoblast cells (7F2) were obtained from the Food Industry Research and Development Institute, Taiwan, and refined in Dulbecco's Modified Eagle's Medium (DMEM). They were further strengthened with $10 \% \mathrm{v} / \mathrm{v}$ fetal bovine serum (FBS), 100 units $/ \mathrm{mL}$ penicillin, and $100 \mu \mathrm{g} / \mathrm{mL}$ streptomycin. Cells were refined in an incubator with $5 \% \mathrm{CO}_{2}$ at $37^{\circ} \mathrm{C}$.

\section{Antler materials}

Deer antler of $R$. unicolor was collected in the middle of March 2017 in UPTD (Technical Implementation Service Unit) of East Kalimantan, Indonesia, and voucher specimens were deposited at the UPTD of East Kalimantan, Indonesia.

\section{$R$. unicolor antler extraction}

R. unicolor antler was obtained from UPTD of East Kalimantan, Indonesia. It was powdered $(991 \mathrm{~g})$ and extracted with $70 \%$ ethanol-aqueous (2.0 Lx3) using maceration. The $70 \%$ ethanol solution was concentrated using a rotary evaporator to obtain $70 \%$ ethanol extract ( $E t-T L, 35.0 \mathrm{~g}$ ). In addition, the deer antler (430 g) was extracted with $100 \%$ water $(1.0$ Lx 3 ) by applying continuous percolation. The aqueous solution was freeze dried to obtain aqueous extract (A-TL, $6.1 \mathrm{~g})$.

\section{Cell viability assay}

The RAW 264.7 macrophages were cultured at a density of $5 \times 10^{4}$ macrophages/well in 96-well plates using DMEM consisting of $10 \%$ FBS, 100 units $/ \mathrm{mL}$ penicillin, and $100 \mu \mathrm{g} / \mathrm{mL}$ streptomycin for macrophage growth studies. After $24 \mathrm{~h}$, the samples (Et$\mathrm{TL}$ and $\mathrm{A}-\mathrm{TL}$ extracts of $R$. unicolor antler) were incubated at 10,50 , and $100 \mu \mathrm{g} / \mathrm{mL}$ for another $24 \mathrm{~h}$. Afterwards, the medium was discarded and the macrophages were incubated with $200 \mu \mathrm{L}$ of 3-(4,5-dimethylthiazol-2-yl)- and $100 \mu \mathrm{L}$ of 2,5-diphenyltetrazolium bromide (MTT) reagents $(100 \mu \mathrm{g} / \mathrm{mL}$ ) for $4 \mathrm{~h}$. Then $100 \mu \mathrm{L}$ of dimethyl sulfoxide was added to disperse the formazan crystals. The absorbance was determined at $570 \mathrm{~nm}$ using an enzyme-linked immunosorbent assay (ELISA) reader. All treatments were carried out in triplicate and expressed in $\%$ macrophage viability of unprocessed control macrophages. A similar method was carried out on 7F2 osteoblast-like cells at $10^{4}$ cells/well in DMEM containing $10 \%$ FBS, 100 units $/ \mathrm{mL}$ penicillin, and $100 \mu \mathrm{g} / \mathrm{mL}$ streptomycin. ${ }^{21}$

\section{Nitrite measurement}

The $5 \times 10^{5}$ cells/well of RAW 264.7 macrophages were seed in 24-well plates and incubated with DMEM containing $10 \%$ FBS, 100 unit $/ \mathrm{mL}$ penicillin, and $100 \mu \mathrm{g} / \mathrm{mL}$ streptomycin for $24 \mathrm{~h}$. The macrophages were activated with $500 \mathrm{ng} / \mathrm{mL}$ lipopolysaccharide (LPS) and evaluated with samples (Et-TL and A-TL extracts) at $10-100 \mu \mathrm{g} / \mathrm{mL}$ for 1 day. The emitted NO was estimated by weighing the nitrite concentration. Then 100 
$\mu \mathrm{L}$ of samples were added with $100 \mu \mathrm{L}$ of Griess reagent to 96well plates for $15 \mathrm{~min}$ at room temperature. An ELISA reader was used to measure the absorbance at $550 \mathrm{~nm}$. Furthermore, curves of standard calibration were processed using $\mathrm{NaNO}_{2}$ to evaluate nitrite expression of macrophages with sensitivity and linear range values of $2.5 \mu \mathrm{M}$ and $20-100 \mu \mathrm{M}$, respectively. ${ }^{21}$

\section{Differentiation of alkaline phosphatase activity}

The $10^{4}$ cells/well of 7F2 osteoblast cells were plated in 24-well plates using DMEM containing $10 \% \mathrm{FBS}, 50 \mu \mathrm{g} / \mathrm{mL}$ ascorbic acid, and $5 \mathrm{mM} \beta$-glycerol phosphate ( $\beta$-GP) with or without $10-100 \mu \mathrm{g} / \mathrm{mL}$ Et-TL and A-TL extracts for 4 days of incubation $\left(37^{\circ} \mathrm{C}\right.$ in a $5 \% \mathrm{CO}_{2}$ atmosphere). Phosphate buffer saline (PBS) was used to wash the extracted supernatants. After that, a percentage of $v / v$ triton solution was added, followed by incubation for $10 \mathrm{~min}$ at $37^{\circ} \mathrm{C}$. For the ALP assay, the cell lysates were added with $200 \mu \mathrm{L}$ of $p$-nitrophenyl phosphate and di-ethanolamine buffer to each well for $30 \mathrm{~min}$ at room temperature. Then $50 \mu \mathrm{L} /$ well $\mathrm{NaOH}$ solution was added to end the reaction, while an ELISA reader at $405 \mathrm{~nm}$ was used to evaluate the absorbance. ${ }^{21}$

\section{Mineralization of the extracellular matrix}

One milliliter of DMEM comprising $5 \mathrm{mM} \beta$-GP, $50 \mu \mathrm{g} / \mathrm{mL}$ ascorbic acid (2GF medium), and 10\% FBS was used to seed $10^{4}$ cells/well of 7F2 osteoblast cells for 7 days in an incubator; $10-100 \mu \mathrm{g} / \mathrm{mL}$ of Et-TL and A-TL extracts were also added to the growth medium. After 7 days, PBS and $75 \% \mathrm{v} / \mathrm{v}$ ethanol were used to wash the samples and they were dried at room temperature. The cells were dyed with $200 \mu \mathrm{L}$ of $1 \%$ ARS for 1 h. A Nikon TI-E microscope and SPOT RT3 camera were used to record images of the cell morphology. Each well received $10 \% \mathrm{w} / \mathrm{v}$ cetylpyridinium chloride $(400 \mu \mathrm{L})$ and was rocked for $10 \mathrm{~min}$ in order to disperse the calcium. The absorbance was finally evaluated at $560 \mathrm{~nm}$ using an ELISA reader. ${ }^{21}$

\section{Statistical analysis}

The experiments were carried out for three more consecutive times with similar sample. They are presented as mean \pm standard deviations. The paired t-test was used for the data analysis. The differences were significant at $p<0.05$.

\section{RESULTS}

The effect of antler extract on cell viability and nitric oxide production

In the present research, the effects of Et-TL and A-TL extracts against inflammation associated with bone turnover were analyzed. Several researchers have reported the bioactivity impacts of deer bones and antlers from various nations, but there is no information on the pharmacological activity of deer antlers originating from Indonesia ( $R$. unicolor). ${ }^{7,22-24}$

Cytotoxic test samples (Et-TL and A-TL extracts) at different concentrations were incubated with RAW 264.7 macrophages for 1 day and were evaluated using the MTT method. Then the data were represented as the average cell viability. The A-TL extract did not show cytotoxicity compared to Et-TL extracts (Figure 1), while the macrophage viability in Et-TL extracts ( 50 and $100 \mu \mathrm{g} / \mathrm{mL}$ ) decreased significantly. Thus, the aqueous extract was not toxic toward the macrophages at the concentration series of $10-100 \mu \mathrm{g} / \mathrm{mL}$ and was able to increase the cellular permeation of constituents therein.

The anti-inflammatory test of samples in RAW 264.7 macrophages stimulated by LPS was conducted by monitoring the NO inhibition. The Griess reagent was used to evaluate the nitrite value directly related to the amount of NO production in RAW 264.7 macrophages. These macrophages were treated with samples, after which the NO produced in the LPSstimulated RAW 264.7 macrophages deteriorated significantly (Figure 2). The Et-TL extract prevented NO production up to $40 \%$ in $10 \mu \mathrm{g} / \mathrm{mL}$. Similarly, A-TL extract reduced it up to $80 \%$ in the same concentration. LPS ( $500 \mathrm{ng} / \mathrm{mL}$ ) in macrophages was not used as a control group because it had a total nitrite value of $100 \%$.

\section{The effect on ALP stimulation of 7F2 osteoblasts of $70 \%$ ethanol and aqueous extracts of deer antler}

The effect of samples (Et-TL and A-TL extracts) on 7F2 osteoblastic cell line proliferation was determined by MTT test. The viability of cells in Et-TL extract decreased significantly ( 50

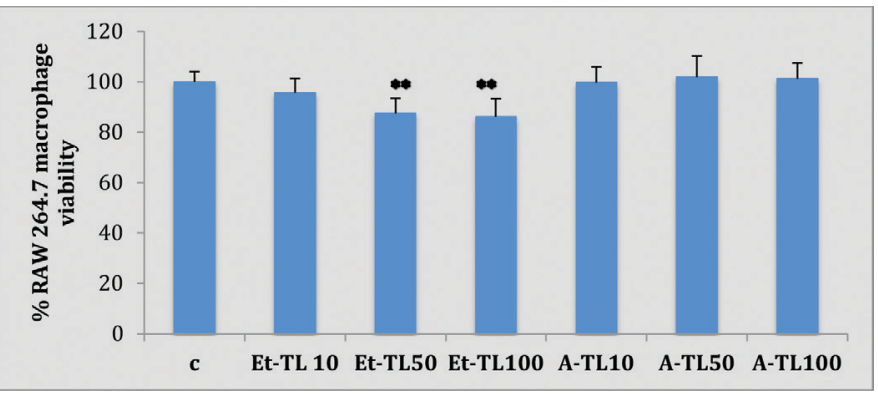

Figure 1. The effects of samples at 10, 50, and $100 \mu \mathrm{g} / \mathrm{mL}$ on RAW 264.7 macrophage viability; $C$ was the control medium without samples, Et-TL was $70 \%$ ethanol extract, A-TL was aqueous extract. Data are shown as the average of \% cell viability to control for $24 \mathrm{~h} \pm$ standard deviation

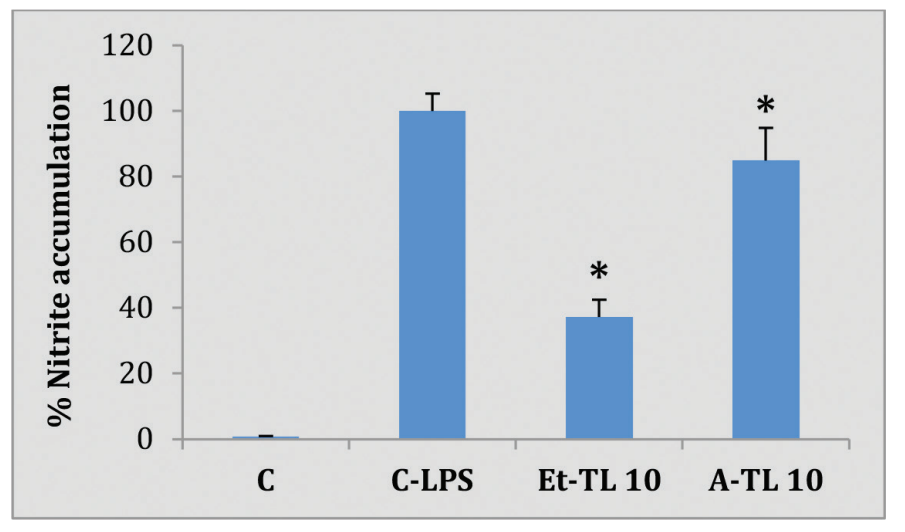

Figure 2. The effects of samples at $10 \mu \mathrm{g} / \mathrm{mL}$ on NO production in LPS ( 500 $\mathrm{ng} / \mathrm{mL}$ )-induced RAW 264.7 macrophages for $24 \mathrm{~h}$; C-LPS was control of LPS, $C$ was cells of the control group were not induced with LPS, Et-TL was $70 \%$ ethanol extract, A-TL was aqueous extract. The total nitrite produced by the cells of the LPS group is revealed as $100 \%$. Results are shown as $\%$ of average \pm standard deviation. ${ }^{*} p<0.05$ with respect to control NO: Nitric oxide LPS: Lipopolysaccharide 
and $100 \mu \mathrm{g} / \mathrm{mL}$ ), but the value was more than $100 \%$. It showed that a high concentration of Et-TL extract was not toxic even though the cell proliferation value decreased. On the other hand, cell viability of A-TL extract increased significantly (Figure 3). As a result, all deer antler extracts decreased cytotoxicity and raised cellular uptake. Then the ALP and mineralization experiments continued.

The ALP stimulated 7F2 osteoblast cells using Et-TL and A-TL extracts of deer antler were incubated for 4 days. The effects of test samples on the ALP assay increased in the 7F2 osteoblasts as opposed to the $2 \mathrm{GF}$ group. After 4 days, the A-TL and Et-TL extracts stimulated ALP activity to $65 \%$ and $52 \%$, respectively (Figure 4).

\section{The effect on mineralization of 7F2 osteoblasts of $70 \%$ ethanol and aqueous extracts of deer antler}

The 7F2 osteoblast cells were cultured in 2GF medium to prompt osteoblast differentiation and mineralization. After 7 days of incubation, the effects of Et-TL and A-TL extracts of deer antler on osteoblast mineralization were examined using ARS, which determined the calcium content in the bone matrix. The Et-TL extract displayed stimulation of cell differentiation (Figure 4) and after 7 days this extract stimulated mineralization. The A-TL extract displayed better stimulation mineralization than $70 \%$ ethanol extract of deer antler (Figure 5).

The stains on ARS represented mineral deposits and were quantified by cetylpyridinium chloride extraction. The treated 7F2 osteoblast cells increased the ARS accumulation compared to the 2GF group. Photographs were used to represent the

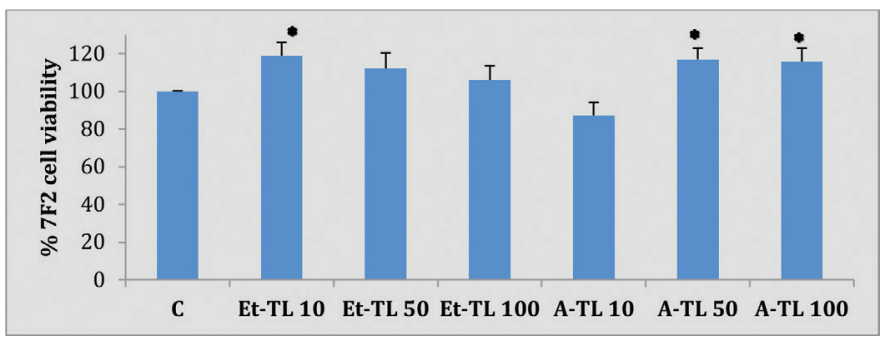

Figure 3. The effects of samples at 10,50 , and $100 \mu \mathrm{g} / \mathrm{mL}$ on $7 \mathrm{~F} 2$ cell viability; C was medium without sample, Et-TL was $70 \%$ ethanol extract, A-TL was aqueous extract. Data are shown as the average of $\%$ cell viability compared to control for $24 \mathrm{~h} \pm$ standard deviation

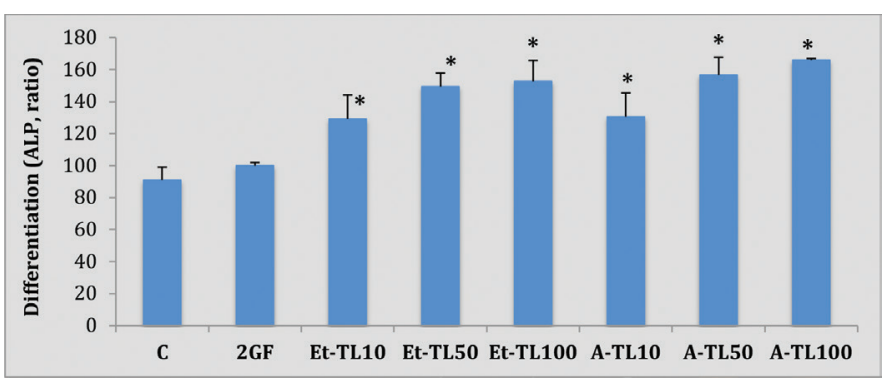

Figure 4. The effects of samples at 10,50 , and $100 \mu \mathrm{g} / \mathrm{mL}$ on osteoblast differentiation (ALP) during 4 days of incubation; Et-TL was $70 \%$ ethanol extract, A-TL was aqueous extract. The 7F2 osteoblast cells were cultured in 2GF medium to produce osteoblast differentiation. Results are shown as $\%$ with average \pm standard deviation. ${ }^{*} p<0.05$ with respect to $2 \mathrm{GF}$ ALP: Alkaline phosphatase mineralization process of osteoblast cells under a bright field. Mineralized nodule formation (red) was high in 7F2 osteoblast cells treated with Et-TL and A-TL extracts on day 7 under microscope observation (Figure 6). Identical patterns were also observed in ALP activity.

\section{DISCUSSION}

Bone metabolism is a lifelong process that occurs because mature bone tissue is lost (osteoclast activity) and new bone tissue is formed (osteoblast activity). Osteoclasts are multinucleated cells and involve nuclear factor kappa-B ligand (RANKL) as a stimulus of receptors and generated by macrophage precursor cells. The RAW 264.7 macrophages have a necessary role in the process of osteoclast formation and function. ${ }^{25}$ Osteoclast function can be impaired due to degeneration of articular cartilage and synovial inflammation involving tumor necrosis factor- $\alpha$, chemokines, and a number of inflammatory cytokines and interleukins (IL) such as IL-1 $\beta, I L-6, I L-11$, and IL-17. They cause bone loss by reducing osteoprotegerin (OPG) production and stimulating RANKL expression in osteoblasts and stromal cells. The NO inhibition of RAW 264.7 macrophages showed a

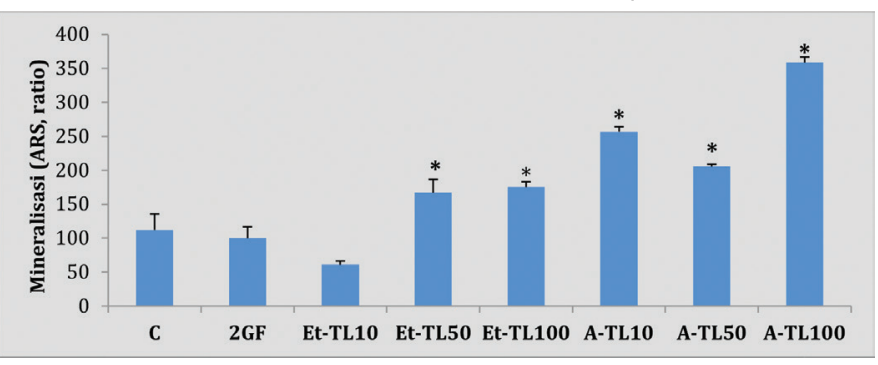

Figure 5 . The effects of samples at 10,50 , and $100 \mu \mathrm{g} / \mathrm{mL}$ on quantification mineralization assay during 7 days of incubation; Et-TL was $70 \%$ ethanol extract, A-TL was aqueous extract. ARS dye was measured by cetylpyridinium chloride extraction. The results are shown as \% with average \pm standard deviation. ${ }^{*} \mathrm{p}<0.05$ with respect to $2 \mathrm{GF}$ ARS: Alizarin red staining

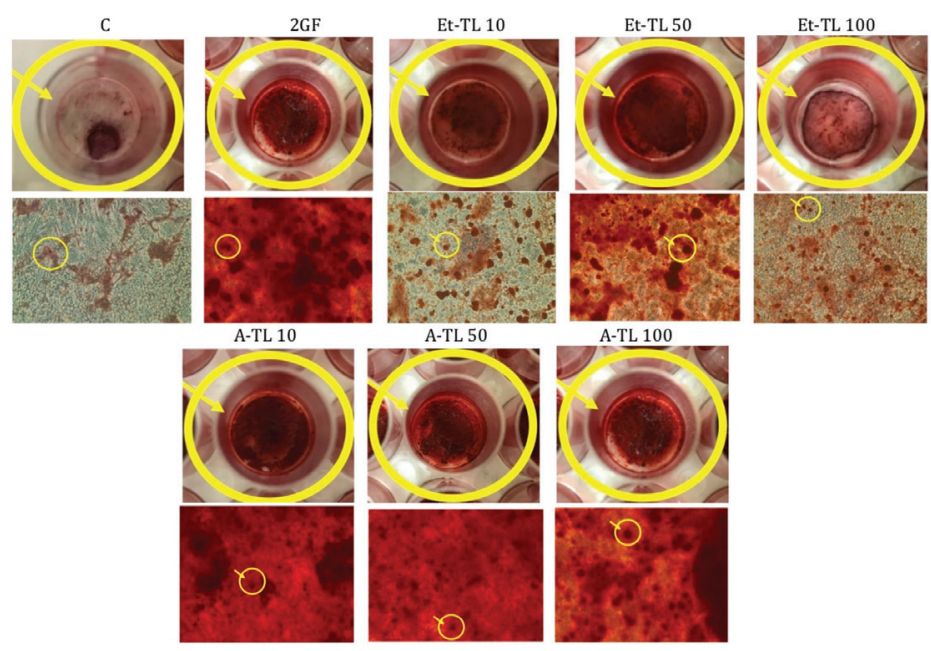

Figure 6. Histochemical staining of mineral deposition of samples at 10 , 50, and $100 \mu \mathrm{g} / \mathrm{mL}$; Et-TL was $70 \%$ ethanol extract, A-TL was aqueous extract. They were visualized using ARS staining (100x magnification). Red staining represents mineral deposition ARS: Alizarin red staining 
decrease in cytokine inflammation, thus preventing bone loss by escalating RANKL and OPG levels. ${ }^{21}$

NO inhibition through the $\mathrm{p} 38$, JNK, and NF- $\mathrm{KB}$ signaling pathways' retardation is associated with inflammatory response inhibition and osteoclastogenesis suppression. Yeh et al. ${ }^{21}$ showed that Cur liposomes, as samples, inhibited NO production in RAW 264.7 macrophages and prevented osteoclast differentiation by increasing the OPG/RANKL ratio and decreasing cathepsin $\mathrm{K}$ regulation and tartrate-resistant acid phosphatase expression. The high NO inhibition and OPG/RANKL ratio lead to a reduction in osteoclast activation and a rise in the number of osteoblasts, so that the effect of osteoporosis can be reduced.

In the present study, we evaluated the NO production of $70 \%$ ethanol and aqueous extracts in LPS-stimulated RAW 264.7 macrophages. LPS markedly stimulated NO production in these macrophages compared to in the control group. The $70 \%$ ethanol extract of deer antler showed a higher reaction rate in lowering LPS-stimulated RAW 264.7 than that of aqueous extract (Figure 2). Neither of them had any cytotoxic effect on RAW 264.7 macrophages (Figure 1). According to Choi et al. ${ }^{26}$ the ability of the methanol fraction from deer bone in reducing NO production was the result of decreased regulation and expression of mRNA from pro-inflammatory agents, such as IL-1 $\beta, I L-12 \beta$, and cyclooxygenase. The methanol fraction containing sugar played an essential part in lowering reactions of inflammatory by managing agents and pro-inflammatory cytokines. Proinflammatory cytokine production in large quantities can be found in several conditions, such as arthritis, rheumatoid arthritis, osteoarthritis, osteoporosis, and cancer. ${ }^{27,28}$

The osteoblast phenotype for bone mineralization is obtained in two phases. In the first phase the mature contents and characteristic protein related to the bone cell phenotype such as ALP are detected and in the second phase the contents are mineralized by calcium deposition. A spongy bone layer is formed around the original cartilage and the space between the spongy bones is loaded with bone content and becomes solid bone.

Deer antler is able to stimulate osteoblast proliferation and protein contents in bone such as collagen type 1 and bone sialoprotein and so the antler can trigger osteoblast differentiation through mineralized nodule formation. As expected, the $70 \%$ ethanol and aqueous extracts of deer antler increased ALP activity constantly (Figure 4). The result is similar to that in the research reported by Lee et al. ${ }^{17}$ in which cells plated in media with aqueous extract had more ALP activity than the $70 \%$ ethanol extract. Deer antler significantly increased osteoblast proliferation until $119 \%$ of the basic value, stimulated expression of mRNA and ALP activity in the range of 50-100 $\mathrm{\mu g} / \mathrm{mL}$, and increased type 1 collagen mRNA expression and mineralization to be more than $183 \% .^{17}$

Interestingly, ALP has been proven to be an enzyme that plays an essential role in the mineralization process. Human bone abnormalities and hypophosphatasia can occur due to the absence of expression of ALP bone form ${ }^{29,30}$ and described by a lack of bone mineral deposition (rickets). ALP is important for mineralization but its purpose has not yet been fully clarified. We continued to evaluate the effect of $70 \%$ ethanol and aqueous extracts of deer antler on mineralization activity (Figure 5).

The new bone tissue formed will be implicated in the mechanism of osteoblast proliferation, osteoblast differentiation, and mineralization. The 7F2 osteoblast cells started differentiating on day 4. The ALP assay is displayed as an initial term marker of differentiated cells. Then the mineralization of 7F2 osteoblast cells produced by ARS was monitored. Figure 6 shows that the extracts stimulated the mineralization of 7F2 osteoblast cells. The stimulation of aqueous extract at $100 \mu \mathrm{g} / \mathrm{mL}$ was two times higher than that of $70 \%$ ethanol extract. This difference may be as a result of a reduction in deer antler extract toxicity or chemical constituents in both extracts.

\section{CONCLUSION}

The $70 \%$ ethanol and aqueous extracts of $R$. unicolor antler from Kalimantan had a role in bone remodeling. The aqueous extract stimulated higher bone differentiation and mineralization than the $70 \%$ ethanol extract with an ALP value of $65 \%$ and twice the ARS value. However, the $70 \%$ ethanol extract displayed higher NO inhibition activity than aqueous extract with an inhibition value of $40 \%$. Therefore, the extracts can be considered to effectively degrade inflammatory marker expression in osteoblasts and preserve osteoblast functions.

\section{ACKNOWLEDGMENTS}

This research was supported by Airlangga University (No. 886/ UN3/2018) and was a collaboration between the Faculty of Pharmacy Airlangga University, UPTD of East Kalimantan, and National Chiayi University Taiwan.

Conflict of Interest: No conflict of interest was declared by the authors.

\section{REFERENCES}

1. Jennifer JW. Methods in molecular biology: Osteoporosis methods and protocol, Human Press; 2008.

2. Cooper C, Campion G, Melton LJ $3^{\text {rd. }}$ Hip fractures in the elderly: a world-wide projection. Osteoporos Int. 1992;2:285-289.

3. Kanis JA, Johnell O, Oden A, Sembo I, Redlund-Johnell I, Dawson A, De Laet C, Jonsson B. Long-term risk of osteoporotic fracture in Malmö. Osteoporos Int. 2000;11:669-674.

4. Sudoyo SA, Simadibrata S. Osteoporosis. Buku ajar ilmu penyakit dalam II, $4^{\text {th }}$ ed. Jakarta, FKUI; 2006.

5. Megraj KVK, Raju K, Balaraman R, Meenakshisundaram K. Biological activities of some Indian medicinal plants. JAPER. 2011;1:12-44.

6. Sunwoo HH, Nakano T, Hudson RJ, Sim JS. Isolation, characterization and localization of glycosaminoglycans in growing antlers of wapiti (Cervus elaphus). Comp Biochem Physiol B Biochem Mol Biol. 1998;120:273-283.

7. Kawtikwar PS, Bhagwat DA, Sakarkar DM. Deer antler-traditional use and future perspectives. Indian J Tradit Knowl. 2010;9:245-251. 
8. Mikler JR, Theoret CL, High JC. Effects of topical elk velvet antler on cutaneous wound healing in streptozotocin-induced diabetic rats. J Altern Complement Med. 2004;10:835-840.

9. Shi B, Li G, Wang P, Yin W, Sun G, Wu Q, Yu G. Effect of antler extract on corticosteroid-induced a vascular necrosis of the femoral head in rats. J Ethnopharmacol. 2010;127:124-129.

10. Dai TY, Wang CH, Chen KN, Huang IN, Hong WS, Wang SY, Chen YP, Kuo CY, Chen MJ. The antiinfective effects of velvet antler of Formosan Sambar Deer (Cervus unicolor Swinhoei) on Staphylococcus aureusinfected mice. Evid Based Complement Alternat Med. 2011;2011:534069.

11. Zhang Z, Liu X, Duan L, Li X, Zhang Y, Zhou Q. The effects of velvet antler polypeptides on the phenotype and related biological indicators of osteoarthritic rabbit chondrocytes. Acta Biochim Pol. 2011;58:297302.

12. Kuo CY, Wang T, Dai TY, Wang CH, Chen KN, Chen YP, Chen MJ. Effect of the velvet antler of Formosan Sambar Deer (Cervus unicolor Swinhoei) on the prevention of an allergic airway response in mice. Evid Based Complement Alternat Med. 2012;2012:481318.

13. Shao MJ, Wang SR, Zhao MJ, Lv XL, Xu H, Li L, Gu H, Zhang JL, Li G, Cui $X N$, Huang $L$. The effects of velvet antler of deer on cardiac functions of rats with heart failure following myocardial infarction. Evid Based Complement Alternat Med. 2012;2012:825056.

14. Meng HY, Qu XB, Li N, Yuan S, Lin Z. Effects of pilose antler and antler glue on osteoporosis of ovariectomized rats. Zhong Yao Cai. 2009;32:179-182.

15. Li Y, Zhao Y, Tang R, Qu X. Preventive and therapeutic effects of antler collagen on osteoporosis in ovariectomized rats. Afr J Biotechnol. 2010;9:6437-6441.

16. Yang JH, Cao Y, Wang RL, Fei YR, Zhang H, Feng P, Liu J. Antiresorptive effect of pilose antler blood (Cervus nippon Temminck) in ovariectomized rats. Indian J Exp Biol. 2010;48:554-558.

17. Lee HS, Kim MK, Kim YK, Jung EY, Park CS, Woo MJ, Lee SH, Kim JS, Suh HJ. Stimulation of osteoblastic differentiation and mineralization in MC3T3-E1 cells by antler and fermented antler using Cordyceps militaris. J Ethnopharmacol. 2011;133:710-717.

18. Choi SW, Moon SH, Yang HJ, Kwon DY, Son YJ, Yu R, Kim YS, Kim SI, Chae EJ, Park SJ, Kim SH. Antiresorptive activity of bacillus-fermented antler extracts: inhibition of osteoclast differentiation. Evid Based Complement Alternat Med. 2013;2013:748687.
19. Jeon B, Kim S, Lee S, Park P, Sung S, Kim J, Moon S. Effect of antler growth period on the chemical composition of velvet antler in sika deer (Cervus nippon). Mamm Biol. 2009;74:374-380.

20. Tseng SH, Sung HC, Chen LG, Lai YJ, Wang KT, Sung CH, Wang CC. Effects of velvet antler with blood on bone in ovariectomized rats. Molecules. 2012;17:10574-10585.

21. Yeh CC, Su YH, Lin YJ, Chen PJ, Shi CS, Chen CN, Chang HI. Evaluation of the protective effects of curcuminoid (curcumin and bisdemethoxycurcumin)-loaded liposomes against bone turnover in a cell-based model of osteoarthritis. Drug Des Dev Ther. 2015;9:22852300.

22. Kuo CY, Cheng YT, Ho ST, Yu CC, Cheng MJ. Comparison of antiinflammatory effect and protein profile between the water extracts from Formosan sambar deer and red deer. J Food Drug Anal. 2018;26:12751282.

23. Wu F, Li H, Jin L, Li X, Ma Y, You J, Li S, Xu Y. Deer antler base as a traditional Chinese medicine: a review of its traditional uses, chemistry and pharmacylogy. J Ethnopharmacol. 2013;145:405-415.

24. Suh HJ, Lee H, Min BJ, Jung SU, Jung EY. Effects of gangliosides from deer bone extract on the gene expressions of matrix metalloproteinases and collagen type $\mathrm{II}$ in interleukin-1 $\beta$-induced osteoarthritic chondrocytes. Nutr Res Pract. 2016;10:569-574.

25. Collin-Osdoby P, Osdoby P. RANKL-mediated osteoclast formation from murine RAW 264.7 cells. Methods Mol Biol. 2012;816:187-202.

26. Choi HS, Im S, Park Y, Hong KB, Suh HJ. Deer bone oil extract suppresses lipopolysaccharide-induced inflammatory responses in RAW 264.7 cells. Biol Pharm Bull. 2016;39:595-600.

27. Landskron G, De la Fuente M, Thuwajit P, Thuwajit C, Hermoso MA. Chronic inflammation and cytokines in the tumor microenvironment. J Immunol Res. 2014;2014:149-185.

28. Mclnnes IB, Schett G. Cytokines in the pathogensis of rheumatoid arthritis. Nat Rev Immunol. 2007;7:429-442.

29. Caswell AM, Russell RG. Identification of ecto-nucleoside triphosphate pyrophosphatase in human articular chondrocytes in monolayer culture. Biochem Biophys Acta. 1985;847:40-47.

30. Chuck AJ, Patrick MG, Hamilton E, Wilson R, Doherty M. Crystal deposition in hypophosphatasia: a reappraisal. Ann Rheum Dis. 1989;48:571-576. 